
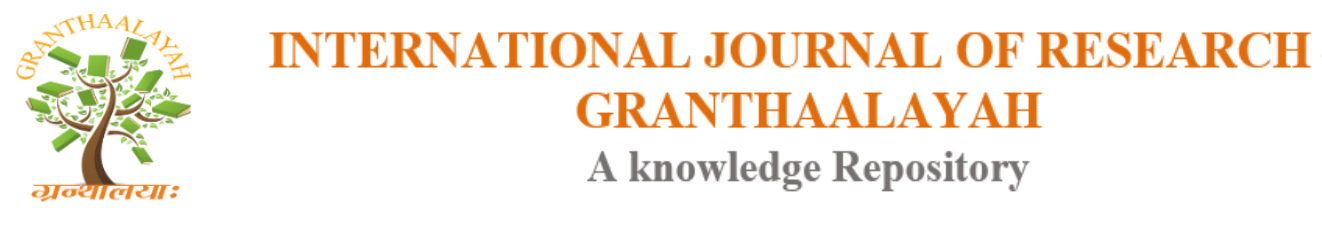

Social

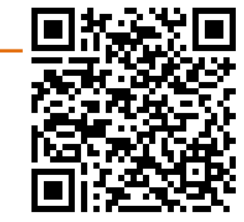

\title{
ASSESSMENT OF WATER AND ENVIRONMENTAL SANITATION SERVICES OF PRIMARY EDUCATION (KHALWA) AT EAST NILE LOCALITY, SUDAN, 2017
}

\author{
Hadeel Mohamed ${ }^{1}$, Fatima Fadul Ali ${ }^{2}$, Mohamed Osman Elamin ${ }^{3}$, Elmubasher Abd Faraj ${ }^{4}$ \\ ${ }^{1}$ Ministry of Health, Sudan \\ ${ }^{2}$ Department of Health Education. AlAzhri University, Sudan \\ ${ }^{3}$ Faculty of Public Health, Umm-Al-AQura University, KSA \\ ${ }^{4}$ Department of Public Health, MoPH, Qatar
}

\begin{abstract}
The descriptive study was conducted in East Nile locality in the period of September to December 2017 to assess the water and environmental sanitation services of primary education instituations (Khalwa). Unsafe water, inadequate sanitation, and insufficient hygiene practices account for an estimated 9.1 percent of the global burden of disease and 6.3 percent of all deaths.

The study aimed to assess the healthy environment, the availability of water supply and water services in khalwas, the ways of collection and disposal of solid waste and health awareness among students towards personal hygiene.

The students (384students) selected randomly from (5135students) and the data was collected by questionnaire and checklist from 4khalwas.

The study results revealed that $(96.4 \%)$ of students their education level is just khalwa, (32.8\%) of students don't know the important of personal hygiene, $(50 \%)$ of khalwas the source of water is wells, (50\%) of khalwas don't have containers for solid waste and it's burning solid waste and (75\%) of khalwas have just two meals per day.

The study was recommended that to increase the awareness of students towards personal hygiene, provision of containers and cars for solid waste in each khalwas, providing network for drinking water and for wastewater and increase the number of rooms according to the number of students.
\end{abstract}

Keywords: Sanitation; Locality; Water.

Cite This Article: Hadeel Mohamed, Fatima Fadul Ali, Mohamed Osman Elamin, and Elmubasher Abd Faraj. (2018). "ASSESSMENT OF WATER AND ENVIRONMENTAL SANITATION SERVICES OF PRIMARY EDUCATION (KHALWA) AT EAST NILE LOCALITY, SUDAN, 2017." International Journal of Research - Granthaalayah, 6(7), 16-22. https://doi.org/10.29121/granthaalayah.v6.i7.2018.1279.

\section{Introduction}

Safe drinking water, sanitation and good hygiene are fundamental to health, survival and development $\{1\}$ yet; 1.1 billion people in the world lack access to improved water supplies and 
2.6 billion people lack adequate sanitation $\{2\}$. Unsafe water, inadequate sanitation, and insufficient hygiene practices account for an estimated 9.1 percent of the global burden of disease and 6.3 percent of all deaths, according to the World Health Organization (WHO) $\{3\}$.

The proportion of the population using an improved sanitation facility throughout Africa was 38 percent in 2006.The largest proportion is in Northern Africa, at 68 per cent, and lowest in western Africa at 24per cent. In western and southern Africa the proportion, sharing sanitation facilities is largest, 22 and 21 per cent respectively. Open defecation is highest in Eastern Africa where 33 per cent of the population does not use any type of sanitation facility. Eastern Africa however saw 25per cent decline in open defecation. From 4 to 33 per cent. One in four people in Africa still practice open defecation. $\{4\}$

Sudan is the largest country in Africa, covering an area of 2.5 million square kilometer between latitudes ${ }^{\circ}$ 03:00 and ${ }^{\circ} 23: 00$ North and longitudes ${ }^{\circ}$ 21:45 $\mathrm{E}$ and ${ }^{\circ} 38: 30$ west with a total population of 39.2 million people (according to 5th Sudan Population Census in 2008) The poor water supply and Environmental sanitation situation is attributed to many factors, including lagging water development works, inadequate awareness for the need of sanitary living, poverty, unavailability of water supply and Environmental sanitation policy, planning and management difficulties, inadequate funding and the huge population displacement and disruption due to successive emergencies. $\{5\}$

Only $27 \%$ of people in Sudan use an improved sanitation facility, while $40 \%$ of people in Sudan have no access to an improved water source. 1.4 million (IDPs) living in Darfur camps are dependent on life saving water, sanitation and hygiene services. Need for new or improved water, sanitation and hygiene services for 200,00 returnees (IDPs and refugees) in their areas of origin in Darfur. Even though conflict affected areas of south kordofan, Blue Nile and Abyei remain largely un-assessed, there are an estimated 1.29 million people in urgent need of water, sanitation and hygiene related assistance in these areas. Urgent water, sanitation and hygiene needs for people of south Sudanese origin residing in open departure points in Khartoum. $\{6\}$

Khalwa are dedicating place for teaching and memorization QURAN.

Kalwa in Sudan are the basis of knowledge and science and are created by generation. the environment comes at the forefront of what must care about him in khalwa.

\section{Objectives}

\subsection{General Objective}

To assess the water and environmental sanitation services of primary education (khalwas) at the East Nile locality 2017.

\subsection{Specific Objectives}

1) To assess the availability of water supply and water services in khalwas.

2) To assess the healthy environment in khalwas. 
3) To identify the ways of collection and disposal of solid waste.

4) To evaluation the level of health awareness among students towards personal hygiene.

\section{Materials and Methods}

Study design: The study descriptive study.

Study Area: East Nile locality is located in Khartoum the capital of Sudan between longitude and latitude 16.5 north and 32.5 East, in the north part of locality found river Nile state, in south blue Nile and east eastern Nile locality and from western river Nile. The total capita area about $45.59 \mathrm{Km}$, it comprise of three administrative unit baladiat bahri, Bahri north and rural bahri, it is compose 22 sectors, 155 villages.

Study Population: The study conducted in 22khalwa shargelnil locality. the target population 5135 students coming from different state of Sudan and from different tribe.

Sample Size and Sampling Technique: Sample size will be 384 according to the calculation by below equation.

Calculated by formula:

$$
\mathrm{n}=\frac{\mathrm{Z}^{2} \mathrm{Pq}}{\mathrm{d}^{2}}
$$

Chose 4khalwas by using randomly selected.

Data Collection Methods: To achieve the purpose of this study data was collected by the adoption of following tools:

Questionnaire: Directed to khalwas supervisors and students to gain information about water supply, solid waste and personal hygiene of students.

Annex number "1".

Check list: annex number "2".

Data Analysis: Data were analyzed using (SPSS version 20). And the results were being presented.

Table 1: knowledge about personal hygiene importance in shargelnil khalwas (2017)

\begin{tabular}{|l|l|l|}
\hline & Frequency & Percent \\
\hline Yes & 258 & 67.2 \\
\hline No & 126 & 32.8 \\
\hline Total & $\mathbf{3 8 4}$ & $\mathbf{1 0 0 . 0}$ \\
\hline
\end{tabular}

2/3 (67.2) of students know about the important of personal hygiene. 
Table 2: Degree of care of students towards cleaning Khalwa in shargelnil khalwas (2017)

\begin{tabular}{|l|l|l|}
\hline & Frequency & Percent \\
\hline Very much & 193 & 50.3 \\
\hline Medium care & 172 & 44.8 \\
\hline I don't care at all & 19 & 4.9 \\
\hline Total & $\mathbf{3 8 4}$ & $\mathbf{1 0 0 . 0}$ \\
\hline
\end{tabular}

Half of students $(50.3 \%)$ take care very much about the cleaning of khalwa.

Table 3: Practice of students towards washing hands in shargelnil khalwas (2017)

\begin{tabular}{|l|l|l|}
\hline & Frequency & Percent \\
\hline Yes & 378 & 98.4 \\
\hline No & 6 & 1.6 \\
\hline Total & $\mathbf{3 8 4}$ & $\mathbf{1 0 0 . 0}$ \\
\hline
\end{tabular}

The majority of students $(98.4 \%)$ washing their hands.

Table 4: Practice of Bathing among students in shargelnil khalwas (2017)

\begin{tabular}{|l|l|l|}
\hline & Frequency & Percent \\
\hline Yes & 378 & 98.4 \\
\hline No & 6 & 1.6 \\
\hline Total & $\mathbf{3 8 4}$ & $\mathbf{1 0 0 . 0}$ \\
\hline
\end{tabular}

The majority of students $(98.4 \%)$ bathing.

Table 5: Practice of students towards washing hair in shargelnil khalwas (2017)

\begin{tabular}{|l|l|l|}
\hline & Frequency & Percent \\
\hline Yes & 374 & 97.4 \\
\hline No & 10 & 2.6 \\
\hline Total & $\mathbf{3 8 4}$ & $\mathbf{1 0 0 . 0}$ \\
\hline
\end{tabular}

The majority of students $(97.4 \%)$ washing their hair.

Table 6: The trimmed of nails among students in shargelnil khalwas (2017)

\begin{tabular}{|l|l|l|}
\hline & Frequency & Percent \\
\hline Yes & 369 & 96.1 \\
\hline No & 15 & 3.9 \\
\hline Total & $\mathbf{3 8 4}$ & $\mathbf{1 0 0 . 0}$ \\
\hline
\end{tabular}

The majority of students $(96.1 \%)$ trimmed their nails.

Table 7: Methods used to clean eyes in shargelnil khalwas (2017)

\begin{tabular}{|l|l|l|}
\hline & Frequency & Percent \\
\hline Tissue & 0 & 0.00 \\
\hline Hand & 273 & 71.1 \\
\hline Water & 109 & 28.4 \\
\hline Other & 2 & 0.5 \\
\hline Total & $\mathbf{3 8 4}$ & $\mathbf{1 0 0 . 0}$ \\
\hline
\end{tabular}

Most of students $(71.1 \%)$ using hand in eye cleaning. 
Table 8: Knowledge of students about the benefits of brushing teeth in shargelnil khalwas

\begin{tabular}{|l|l|l|}
\multicolumn{1}{|c}{ (2017). } & Frequency & Percent \\
\hline Fight cavity & 63 & 18.1 \\
\hline Make tooth clean & 51 & 14.7 \\
\hline Make good mouth smell & 71 & 20.4 \\
\hline Others (religious believes) & 163 & 46.8 \\
\hline Total & $\mathbf{3 4 8}$ & $\mathbf{1 0 0 . 0}$ \\
\hline
\end{tabular}

The benefits of brushing teeth, fight cavity (18.1\%), make tooth clean (14.7\%). Make good mouth smell $(20.4 \%)$ and others $(46.8 \%)$

\section{Discussion}

The study conducted in 4khalwas in shargelnil locality to assess the water and environmental sanitation services.

$2 \mathrm{khalwas}$ the main source of water is general network and in $2 \mathrm{khalwas}$ wells is the source of water (table1) according to ministry of health (2011) common water sources are, rainwater, surface water and ground water.

$2 \mathrm{khalwas}$ store water in drums and it is covered by good way so no way to contaminate of water, and $2 \mathrm{khalwas}$ store water in basins and it is not covered so that may lead to contaminated of water. According to Howard (2002) the top of the water container should be covered to stop dust and other contaminants falling into the drinking-water.

Table"7" show that $100 \%$ of khalws had a toilet facility but different in the technology used. The majority $(75 \%)$ of the khalwas had modern latrine while $(25 \%)$ a traditional latrine, the study by jerry E.2013 showed that (75\%) of schools had access pit latrine which $(25 \%)$ of the school had access to flush toilet facility.

The number of latrine is simple according to the number of students in khalwas.

$2 \mathrm{khalwas}$ store solid waste in containers and then disposal in waste car, and $2 \mathrm{khalwas}$ collect waste in special place (no containers) and then burned (this is dangerous cause it may lead to general burned and also lead to air pollution).

The finding showed 3khalwas have two meals per day and 1khalwas have one meal per day. Hygienic practices were consistent across the four khalwas.

The age of students in 4khalwas (39.6\%) from 5-10 and (60.4/\%) more than 10, and that may affect in the knowledge of students and make them more awareness (table1).

Average percentage of students when asked if they had ever heard about personal hygiene agreed (67.2\%) while (32.8\%) never heard about personal hygiene. According to ministry of health (2011) personal hygiene is employed to prevent or minimize the incidence and spread of communicable diseases. 
$1.3 \%$ of students do not know the specify place of defecate, so they defecate outside and do not use bathroom and these lead to spread of disease vectors, according to Howard (2002) Poorly drained storm water forms stagnant pools that provide breeding sites for disease vectors.

The study showed that $(98.4 \%)$ of students washing their hands, but not all of them using soap and water, $(3.2 \%)$ of them using just water, and also most of them $(41.7 \%)$ washing their hands just before meals, $(33.3 \%)$ washing their hands just after meals and little percent after using bathroom (13.3\%), according to ministry of health(2011) you need to wash your hands after using the toilet, before preparing and handling cooked/ready-to-eat food, before eating food or feeding children, after contact with contaminated surfaces. The studies of O'Reilly et al involving students in western Nyanza district of Kenya showed similar patterns as ours that the majority of the students / learners washed their hands before eating and after using the toilet.

The majority of students (99.2\%) know about the benefits of cutting nails, but most of them $(33.1 \%)$ their knowledge not by health way but by religious way (prevent the devil) and that belong to their study level (most of them study just on khalwas) and according to ministry of health (2011) Keeping nails trimmed and in good shape weekly is important in maintaining good health.

(9.4\%) of students don't know the benefits of brushing teeth and other who know the benefits most of them so the benefits by religious way. And also, the majority of students brushing their teeth one time per day and according to ministry of health (2011) Brush your teeth with a fluoridecontaining toothpaste twice a day - before breakfast and before you go to bed.

The majority of students $(51.3 \%)$ don't change their clothe continuously and they change it day after day, and according to ministry of health (2011) Clothes hygiene is an important aspect of one's dignity and Changing used clothes for clean ones every day is recommended.

The environment of khalwas it's not suitable for students, there is no adequate lights specially artificial lights, and also the ventilation isn't not adequate, and also the size of room of the sleeping is not suitable for students (the size of room $4 \times 6=24 \mathrm{~m} 2$ ) and the number of students in each room are (13 students) and this number are big number and that lead to overcrowding, and according to ministry of health (2011) Based on the requirement to satisfy physiological needs, a minimum of 9-10 m2 per individual is advised.

\section{Conclusion}

- The source of water in half of khalwas is a well.

- Half of khalwas don't have wastewater network and have traditional latrine.

- The majority of khalwas don't have containers to collect solid waste, and it's burned the waste.

- The car of waste coming one time per week in half of khalwas.

- The majority of khalwas having just two meals per day for students.

- Half of students don't care about cleaning of khalwas.

- Less than half of students don't know the important and the benefits of personal hygiene.

- The majority of students don't washing their hands in the specific time (before meal, after meal and after using bathroom). 
- The majority of students brushing their teeth one time per day.

- Most of students don't changing their cloth continuously.

- The number of rooms not enough per the number of students.

- The light and ventilation were not adequate.

\section{Recommendations}

The study recommended following to be implemented by infrastructure department to

- Provide safe water in all primary education institutions (khalwas)

- Provide wastewater network in all primary education buildings (khalwas).

The study recommended to the ministry of health to

- Provide containers for solid waste in all khalwas with frequent disposal.

- Increase the awareness of students towards personal hygiene and cleanness of khalwas.

The study recommended to the supervisor of khalwas to

- provide three meals per day.

- Increase the number of rooms in all khalwas according to the number of students.

- Increase the number of artificial lights and ventilation in all khalwas.

\section{References}

[1] World Health Organization \& United Nations Children's Fund. 2006.

[2] Global challenges in water, sanitation and health. Journal of Water and Health.

[3] Safer water, better health: costs, benefits and sustainability of interventions to protect and promote health. Geneva: World Health Organization (WHO).

[4] A snapshot of sanitation in Africa 2008.

[5] Water supply and environmental sanitation policy, Republic of Sudan.

[6] Sudan water, sanitation and hygiene sector fact sheet.

[7] Ministry of health. Hygiene and environmental health, part2: Blended learning module for the health extension program. Addis Ababa 2011.

[8] World health organization WHO (Fact sheet, Drinking water) updated 2017.

[9] Bradley D j, Chapter in human rights in health. Giba foundation symposium 1974.

[10] United Nation Children Fund. UNICEF handbook on water quality. New York 2008.

[11] Guy Howard, Healthy villages: A guide for communities and community health workers. WHO Geneva 2002.

[12] The state of environmental sanitation in the Accra Metropolitan Area. Pentecost press, Accra. Ghana 2002.

[13] Roland Schertenleib, An Integrated Approach To environmental Sanitation and Urban Agriculture 2002.

[14] Ministry of health. Hygiene and environmental health, part1: Blended learning module for the health extension program. Addis Ababa 2011.

*Corresponding author.

E-mail address: mohsm71@ yahoo.com 